\title{
Consensus
}

Volume 20

Issue 2 In Praise of Valiant Women

Article 28

$11-1-1994$

\section{Integrative Family Therapy}

Sandra A. McCarl

Follow this and additional works at: http://scholars.wlu.ca/consensus

\section{Recommended Citation}

McCarl, Sandra A. (1994) "Integrative Family Therapy," Consensus: Vol. 20 : Iss. 2 , Article 28.

Available at: http://scholars.wlu.ca/consensus/vol20/iss2/28

This Book Reviews is brought to you for free and open access by Scholars Commons @ Laurier. It has been accepted for inclusion in Consensus by an authorized editor of Scholars Commons @ Laurier. For more information, please contact scholarscommons@wlu.ca. 
is Jesus?, 1:1-4:11; Two-The Messiah's Ministry to Israel, 4:12-16:12; and Three- The Messiah's Obedient Submission to Death, 16:13-28:30. Each of these parts is divided by the flow of the story line, often corresponding to lectionary readings.

Hare asserts with Kähler that the Gospel is "a passion narrative with an extended introduction". "Its dominant characteristic... is its moral earnestness" (p. 1). Faith in Christ is more than hearing; it is to be lived daily in obedience, as proclaimed by the evangelist.

Throughout the commentary, the author makes many references to corresponding passages in the Hebrew Bible. He also makes connections with the other Gospels and the rest of the New Testament, so much so that reading this commentary would familiarize one very well with the development of the canon. The reader very early on is brought into the midst of the society in which Jesus ministered, and the one to which Matthew wrote. These are compared and contrasted with our own, and with the issues dominant in the present day. Hare also offers examples of what other commentators have written, especially when there is debate over translation and interpretation. He gives full consideration to passages dealing with the role of women, and argues for a more inclusive approach.

The passages in English are not given in blocks, however, transliterations of the Greek are provided where necessary. Hare does offer his own translations where he considers others lacking, and explains why.

To buy this commentary only to have information on the Gospel would be value enough. However, its real value perhaps lies not in the answers it provides, but in the questions it poses. Hare constantly reminds teachers and preachers of their task by engaging them in the text, by making them stop and think how it relates to the present day, and by challenging their notions of what Matthew meant or means. He keeps both the reader's intellect and imagination in gear, and in so doing succeeds in aiding the proclamation of the Gospel in faithfulness to the 2000 year old intent of its author. Hare's work will not replace other commentaries, but it should have a place alongside those which are more exegetical in nature. His is just as "scholarly" as those, in his own way.

Matthew H. Diegel

Christ Lutheran Church,

Windsor, Ontario

\section{Integrative Family Therapy \\ David C. Olsen \\ Minneapolis: Fortress Press, 1993 \\ 96 pp. $\$ 12.50$}

This volume, Integrative Family Therapy is part of the Creative Pastoral Care and Counseling Series, co-edited by Howard W. Stone and Howard Clinebell. 
The myriad of therapies available today poses a perplexing problem for those in pastoral care and family counselling. Often counselors apply an "integrated eclecticism" that utilizes insights and methods from a variety of sources. Olsen seeks to use a "process of assessment" model for family therapy that integrates the various approaches for assessing and treating family problems in a problem solving method. He examines major disciplines of family therapy and illustrates how they function in assessment and treatment. He includes short-term and long-term cases to illustrate each discipline.

In Chapter 1 Olsen notes the overwhelming task of pastoral care and family therapists within the maze of family therapy models. In particular, Olsen talks about how clergy are involved in many developmental transitions of family life. They perform ritual tasks such as baptism, catechism, weddings and funerals within a family framework and Olsen gives three examples of how complicated this can be.

In Chapter 2 he reviews several disciplines of family therapy, touching on some key concepts of each one. He notes the many aspects of family systems theory as well as developmental theory. He also examines family therapy paradigms.

His integrated model for family therapy addresses these family paradigms as part of the process of assessment. He notes in this chapter that the key concepts of each of these paradigms is the basis of the integrated model for assessment.

In Chapter 3 Olsen introduces an integrative model of assessment using the family therapy paradigms from the previous chapter. He uses a problem-solving approach to map out a "process of assessment".

In Chapter 4 he shows how to follow logically this "process of assessment" approach to set out a treatment plan. In other words, the assessment provides a map that helps the therapist not to get lost in the myriad of treatment issues. The book provides charts to direct the reader through the assessment model as well as several case studies.

The diagrams are helpful because they move sequentially through a number of treatment levels. Likewise, the case studies are very helpful because they are illustrated by using some short-term as well as long-term studies.

Importantly, the assessment model is both sequential and circular in 11ature. Each level opens to another level; problem solving skills display interactional styles which in turn reveal belief systems that originate in fannily of origin and the developmental process. 
In conclusion, therapy that utilizes "a theory from here, a technique from there" with no integrating structure or process runs the risk of unwittingly using concepts and methods that work against one another. Olsen's model provides a map of assessment that integrates the basic paradigms of family therapy and keeps treatment moving in a clear direction. This book is compact and helpful for individuals who are face to face with families as pastoral or family counselors.

Sandra A. McCarl

Conestogo, Ontario

\section{PastorPower}

Martha Ellen Stortz

Nashville: Abingdon Press, 1993

$143 \mathrm{pp}$.

This is "a book for those who love to eat, rather than for those who love to cook". The author, Martha Stortz-Associate Professor of Historical Theology and Ethics at the Pacific Lutheran Theology Seminary in Berkeley, California-explains both the importance and the meaning of this claim when she says: "linger over each chapter, savoring the various ingredients."

This is an engaging, at times provocative, at other times affirming, but always a searching and reflective book on pastor power, on leadership among the people of God. Among the assumptions that the author makes are these three: pastors have power which they exercise in their leadership; pastors are power which they live out in their leadership; pastors hold power which they work with in their leadership.

In describing what this "fine meal" is about, I shall let the author's words speak for themselves:

This book examines three kinds of leadership: "power over," which can be scen as sovereign, parental, or bureaucratic power; "power within" or charismatic power; and "power with" or coactive power. The discussion of each form of power is presented in a case study, and the case study both critiques and illustrates the analysis of the kind of power in question. Finally, these models of leadership are analyzer theologically, from an emerging trinitarian perspective, to sere low theological understandings of power might form, inform, and transform the use of power described (p. 9).

Some time ago, a good friend of mine, who was reflecting with me on the nature of leadership, said: "What you see depends on where you stand." The correctness of this claim is affirmed repeatedly by Stortz as she defines, explores and searches power through varied experiences, parables, perceptions and contexts. To understand power, the stories of power, "one has to 